\title{
Apontamentos sobre a Ditadura Militar brasileira sob a ótica dos historiadores Jacob Gorender e Daniel Aarão Reis
}

\author{
Tests on the Brazilian Military Ditature under the optics of \\ historians Jacob Gorender and Daniel Aarão Reis
}

\author{
Vinícius Viana Juchem ${ }^{1}$ \\ Universidade do Vale do Rio dos Sinos, São Leopoldo, RS, Brasil.
}

\begin{abstract}
Resumo: A ditadura militar no Brasil (1964-1985) significou a ruptura com a experiência democrática que havia sido reestabelecida com o fim do Estado Novo (1937-1945) e a saída de Getúlio Vargas da presidência da República. Seguindo os preceitos da Escola Superior de Guerra (ESG), as Forças Armadas governaram de forma a limitar as possibilidades do exercício da oposição por vias democráticas, seja pela censura aos meios de comunicação, cassação de mandatos políticos ou mesmo fechamento do Congresso Nacional. Além disso, a violência (torturas, assassinatos) foi utilizada pela repressão para derrotar a luta armada. A ditadura militar é, portanto, um período complexo que necessita do trabalho dos historiadores para ser compreendida. Dentre a vasta produção acadêmica sobre o tema, apontamos dois historiadores como referências importantes: Jacob Gorender e Daniel Aarão Reis. Em vista disso, o presente artigo se propõe a analisar algumas concepções dos historiadores citados sobre a ditadura militar e a luta armada. $\mathrm{O}$ artigo tem como objetivo contribuir para $\mathrm{o}$ conjunto de estudos historiográficos sobre a ditadura militar na América Latina, com ênfase no caso brasileiro.
\end{abstract}

Palavras-Chave: Historiografia. Ditadura militar. Luta armada.

\begin{abstract}
The military dictatorship in Brazil (1964-1985) meant the break with the democratic experience that had been re-established with the end of the Estado Novo (1937-1945) and Getúlio Vargas' departure from the presidency of the Republic. Following the precepts of the Escola Superior de Guerra (ESG), the Armed Forces ruled in a way that limited the possibilities of exercising the opposition democratically, whether by censoring the media, revoking political mandates or even closing the National Congress. In addition, violence (torture, murder) was used by repression to defeat the armed struggle. The military dictatorship is, therefore, a complex period that needs the work of historians to be understood. Among the vast academic production on the subject, we point out two historians as important references: Jacob Gorender and Daniel Aarão Reis. In view of this, the present article proposes to analyze some of the historians' conceptions about the military dictatorship and the armed struggle. The article aims to contribute to the set of historiographical studies on the military dictatorship in Latin America, with emphasis on the Brazilian case.
\end{abstract}

Keywords: Historiography. Military dictatorship. Armed struggle.

1 Doutor em História pela Universidade do Vale do Rio dos Sinos - UNISINOS. ORCID: https://orcid.org/0000-0001-7510-9850. E-mail: vianajuchem@bol.com.br 


\section{Jacob Gorender e as esquerdas no Brasil}

Nascido no Estado da Bahia, em 20 de janeiro de 1923, Jacob Gorender é descendente de uma família de imigrantes judeus que vivia em condições de pobreza. De acordo com Gorender (1990, p. 21),

Os cinco filhos e meus pais pertenciam àquela categoria dos judeus sem dinheiro, descritos num romance de Michael Gold, célebre nos anos 30. Morávamos em cortiços e, às vezes, tínhamos dificuldades sérias até para atender necessidades elementares, como alimentação e roupa. Isso marcou minha mentalidade em formação. Mas não só isso: meu pai era um homem de esquerda, anti-sionista - como, aliás, a maioria dos judeus daquela época - e me falava do movimento revolucionário russo. Fizera apenas o curso primário, mas lia avidamente. Exerceu forte influência nas minhas inclinações.

Mesmo com as dificuldades financeiras na infância e adolescência, Gorender prosseguiu os estudos e se matriculou na Faculdade de Direito de Salvador. O envolvimento político com a esquerda ocorreu com o ingresso em uma célula universitária do Partido Comunista Brasileiro (PCB). Com apoio do partido, ele integrou a Força Expedicionária Brasileira (FEB) e combateu na Itália, em 1944. Segundo José (2013), Gorender não retomou os estudos universitários e assumiu a luta política na condição de comunista. No começo dos anos 1950, integrou o Comitê Estadual do PCB, em São Paulo, na companhia do futuro líder da luta armada, Carlos Marighella. Acompanhado de Mário Alves, Apolônio de Carvalho e outros dissidentes do PCB, fundou o Partido Comunista Brasileiro Revolucionário (PCBR), em 1968.

Capturado por agentes da repressão em 20 de janeiro de 1970, Gorender foi torturado e tentou o suicídio ao cortar os pulsos com um pedaço de vidro. Conforme José (2013), “Gorender, preso, torturado, começa a revelar-se como um raro intelectual marxista à margem dos saberes oficiais acadêmicos, autodidata e pesquisador rigoroso".

Para escrever Combate nas trevas- A esquerda brasileira: das ilusões perdidas à luta armada (1987), obra que pode ser considerada que combina elementos de pesquisa acadêmica e reportagem, ele teve a colaboração do cardeal-arcebispo de São Paulo, Dom Paulo Evaristo Arns, que lhe possibilitou o acesso aos documentos do "Projeto Brasil Nunca Mais”. ${ }^{2}$ Além disso, utilizou como fontes históricas as inúmeras entrevistas com ex-guerrilheiros e também suas memórias.

Na condição de escritor, Gorender escreveu os seguintes livros: O escravismo colonial (1978), A burguesia brasileira (1981), Gênese e desenvolvimento do capitalismo no campo brasileiro (1987), A escravidão reabilitada (1990), O fim da URSS: origens e fracasso da Perestroika (1992), Marxismo sem utopia (1999), Brasil em preto \& branco: o passado escravista que não passou (200o), Direitos humanos: o que são (ou devem ser). Além de exercer o ofício de historiador, Gorender também

\footnotetext{
2 O projeto Brasil: nunca mais surgiu no contexto da redemocratização brasileira. Em vista da promulgação da Anistia, em 1979, o governo disponibilizou os processos dos presos políticos no Superior Tribunal Militar (STM) para consulta. Como os documentos poderiam ser retirados pelos advogados dos presos políticos, foi montada uma operação sigilosa que resultou num vasto material que revelou as engrenagens do Poder Judiciário e casos de tortura.
} 
foi tradutor e jornalista. Foi agraciado, em 1999, com o Troféu Juca Pato, prêmio de intelectual do ano, pela União Brasileira de Escritores. Em 2013, Gorener faleceu ${ }^{3}$ aos 90 anos.

Ao mencionarmos a contribuição de Jacob Gorender para o conhecimento histórico sobre a ditadura militar, se faz necessário um olhar mais atento a uma de suas principais obras: Combate nas trevas (1987). De acordo com Rollemberg (2009), o livro é considerado uma pesquisa pioneira sobre a luta armada nas décadas de 1960 e 1970. Ao mesmo tempo testemunha ocular de inúmeros acontecimentos relacionados à esquerda no Brasil e historiador, Gorender não teve a intenção de procurar

uma suposta imparcialidade para dar forma ao trabalho. O resultado é uma pesquisa rigorosa, emocionante e emocionada. Gorender reconstrói a conjuntura da época a partir de uma teia de informações que vai situando o leitor: as teorias que dão forma às organizações se misturam ao factual da vivência da luta armada. Nos 33 capítulos curtos e intensos, repletos de informações e ações, a narrativa aproxima-se do ritmo daqueles anos. (ROLLEMBERG, 2009, p. 49)

Publicado durante o mandato do presidente da República José Sarney (1985-1990), Combate nas trevas assumiu, entre outras coisas, uma posição de crítica ao mito do líder comunista Luiz Carlos Prestes e a atuação da esquerda no período anterior ao golpe de 1964. Também foi abordada a trajetória de várias organizações que atuavam no Brasil nas décadas de 1060 e 1970, como o Partido Comunista Brasileiro (PCB), Partido Comunista do Brasil (PC do B), Partido Comunista Brasileiro Revolucionário (PCBR), a Ação Popular (AP) e a Ação Libertadora Nacional (ALN). Numa entrevista concedida na época do lançamento da obra, Gorender (1987) afirmou que

O grande protagonista do ensaio é a esquerda. Não se trata de um trabalho memorialístico. Apenas uns $15 \%$ referem-se a depoimentos pessoais do autor. E, nessas passagens, me documentei e não me apoiei apenas em minha memória. Não é também um livro sobre a repressão. O Estado repressivo entra como o adversário da esquerda e do movimento popular. Trata-se de um trabalho que resultou de uma pesquisa historiográfica. Neste sentido, é o primeiro livro do gênero publicado no Brasil.

Gorender (1998) se propôs responder a seguinte indagação: por que a guerrilha foi derrotada pela repressão entre 1968 e 1974? A culpa recairia da opção da esquerda de não deflagar a luta armada após o golpe de 1964, pois haveria a possibilidade da vitória. O timing foi errado: quando uma parcela da esquerda pegou em armas, a repressão estava melhor organizada, os movimentos de massa não possuíam a mesma força e a esquerda radical estava isolada do

\footnotetext{
3 Na ocasião, a então presidenta da República Dilma Rousseff enalteceu a memória do historiador: "Autor de duas obras clássicas da historiografia brasileira, O Escravismo Colonial e Combate nas Trevas, Gorender foi um pensador do Brasil. Não teve medo das polêmicas intelectuais, assim como não teve medo de defender suas ideias, mesmo pagando o pior dos preços. Nós nos conhecemos presos no Dops, em São Paulo. Ele estava convalescente de torturas e foi conselheiro importante em um momento crucial na minha vida. Aos familiares, amigos e admiradores, deixo as minhas condolências e homenagens a este grande brasileiro".
} 
proletariado, campesinado e das camadas médias dos grandes centros urbanos. Em outras palavras, o PCB é responsabilizado por não ter resistido ao golpe de forma mais enfática. Numa entrevista, Gorender (1988, p. 149) declarou que

O período que examinei na pesquisa foi o de encaminhamento errado da proposta de conquista do poder para o proletariado no Brasil. Errado, antes de 64, com uma visão de transição pacífica. Quem tinha a primazia no espectro na esquerda era o PCB, com uma visão pacífica da transição. Eu, particularmente, faço autocrítica, pois, naquela época, era dirigente do PCB. Depois da derrota de 64 , a esquerda não percebeu que o inimigo estava fortalecido com um aparelho de Estado expurgado, com o pleno apoio da classe dominante e com as organizações de massa destroçadas. Nessas condições desfavoráveis, engendrou-se a idéia da luta armada e através de caminhos que são criticados no livro, como o foquismo, principalmente.

A questão do uso da violência pelos agentes da repressão e guerrilheiros também é abordada em Combate nas trevas. Para Gorender (1998, p. 269), as organizações de esquerda armada “[...] praticaram atos aqui expostos sem subterfúgios: atentados a bomba e armas de fogo, assaltos a bancos, sequestros de diplomatas e de aviões, matança de vigilantes, policiais e elementos das Forças Armadas, justiçamento de inimigos, guerrilha urbana e rural”. Ao reforçar que a esquerda deveria assumir a autoria de tais atos, salientou que "A violência original é a do opressor, porque inexiste opressão sem violência cotidiana incessante. A ditadura militar deu forma extremada à violência do opressor. A violência do oprimido veio como resposta”. (GORENDER, 1998, p. 269) Percebe-se que a violência da esquerda revolucionária não é deslegitimada pelo autor, uma vez que ela não deve ser dissociada das agressões oriundas da classe dominante.

Um exemplo da violência do opressor é a tortura. Gorender (1998) afirma que a tortura era amplamente utilizada pelos agentes da repressão e tolerada pela hierarquia das Forças Armadas. As sessões de tortura visavam descobrir, da forma mais rápida possível, informações sobre o paradeiro de guerrilheiros e localizações de esconderijos. Para Gorender (1998, p. 258), “A maioria das quedas ocorreu em pontos de rua e em aparelhos denunciados. As prisões em cascata assolavam as organizações e inspiraram o que, no Presídio Tiradentes, se chamou de quedograma [grifo autor]: um gráfico com o quem foi quem na seqüencia de prisões”. Também é mencionada a existência de um perfil de militante político que, teoricamente, suportaria a tortura porque havia interiorizado a ideologia socialista e a utilizava como "[...] norma moral. A origem social não é variável decisiva. Mas a resistência à tortura também remonta à formação da personalidade, da disposição psicológica e fatores situacionais”. (GORENDER, 1998, p. 261-262)

Outra passagem reveladora sobre a luta armada enfoca os dois tipos de justiçamentos, ou seja, a execução de indivíduos considerados inimigos da revolução. No primeiro tipo, as vítimas não integravam as organizações de esquerda armada, como foi o caso de do dinamarquês Henning Boilesen, presidente da Ultragás no começo dos anos 1970, que ajudava financeiramente a OBAN e o DOI/CODI. Além de assistir a sessões de tortura, ele introduziu 
no Brasil um aparelho que, através de um teclado, emitia choques. Em sua homenagem, o dispositivo de tortura recebeu o nome de Pianola Boilesen. Numa ação armada organizada pelo Movimento Revolucionário Tiradentes (MRT) e a Ação Libertadora Nacional (ALN), Boilesen foi assassinado em 15 de abril de 1971. No segundo tipo de justiçamento, o alvo eram os companheiros acusados de trair os ideais da revolução e fornecer informações aos órgãos de repressão. Um exemplo foi o guerrilheiro Márcio Leite de Toledo, executado a tiros após uma votação da direção da ALN. Uma série de fatos colocou em dúvida o seu compromisso com a esquerda armada: desaparecer por 40 dias e não fornecer uma justificativa plausível, apresentar sintomas de pânico, expressar o desejo de deixar a ALN e, por último, recusar a proposta dos companheiros de deixar o país. Gorender (1998, p. 280) ressalta que não foram encontradas provas de que Márcio Leite de Toledo tivesse traído a ALN: "Atribuíram-lhe a culpa da intenção e o fuzilaram pelo crime de intenção. Já na época, houve reprovação em vários setores da esquerda e o comunicado lançado pela direção nacional da ALN não convenceu".

Em Combate nas trevas, Gorender (1998) também dedicou espaço para situar os leitores das dificuldades cotidianas da luta armada: muitos guerrilheiros não queriam ou tinham condições de trabalhar; em vista do crescente número de assaltos, os bancos guardavam menos dinheiro nos cofres; casas que haviam sido alugadas eram abandonadas porque as prisões tornavam o local perigoso e, por último, o dinheiro ${ }^{4}$ confiscado era gasto rapidamente. $\mathrm{O}$ cerco da repressão atingiu com força a esquerda armada:

O guerrilheiro urbano tinha vida ativa mediana em torno de um ano, antes do término pela prisão com sobrevivência ou pela morte. Uma minoria conseguia prolongar a vida ativa até dois anos. Contam-se pelos dedos os pouquíssimos que estiveram em ações armadas durante quatro ou cinco anos e escaparam da prisão pela fuga para o exterior (GORENDER, 1998, p. 228).

Além disso, Gorender (1998, p. 173) também constatou que

[...] os dirigentes revolucionários se afundavam no engano fatal de que a justeza de sua causa, a audácia dos seus feitos e a difusão de suas proclamações lhes garantiriam o apoio das massas oprimidas. [...] O pior de tudo era a perda de militância e de base social. O engajamento total na luta armada afastava militantes e simpatizantes por falta de aptidões pessoais e disposição ideológica. O número de adeptos baixava dos milhares às centenas e às dezenas.

Percebe-se que as dificuldades impostas pela repressão tornaram a luta armada um enfrentamento desigual. Apesar de presos, torturados e derrotados em seu intuito revolucionário, os guerrilheiros venceram a batalha pela memória sobre a ditadura militar.

4 Paradoxalmente, as dificuldades financeiras dos guerrilheiros ocorriam no momento em que a economia brasileira obtinha ótimos resultados: "Era o Milagre Brasileiro. O século XX terminaria sem que o país passasse por semelhante período de prosperidade outra vez." (GASPARI, 2014, p. 213). 
Na edição revisada de Combate das trevas, Gorender (1998) observou que os meios de comunicação já não se referiam aos guerrilheiros como “terroristas” ou "bandidos”. Tal mudança de consciência é creditada ao trabalho da Arquidiocese de São Paulo, das comissões de familiares de presos políticos, do grupo Tortura Nunca Mais e da Comissão Especial de Mortos e Desaparecidos Políticos, criada pelo governo federal na década de 1990.

Uma das principais polêmicas de Combate nas trevas está relacionada à suposta responsabilidade dos dominicanos pelo assassinato de Carlos Marighella, em 4 de novembro de 1969. Severamente torturados pela equipe do delegado Sérgio Paranhos Fleury ${ }^{5}$, os Freis Ivo e Fernando de Britto revelaram seus vínculos com a luta armada e foram usados na cilada que resultou na morte do líder da ALN.

No livro Batismo de sangue (1982), Frei Betto afirma que houve uma conspiração das autoridades brasileiras e internacionais para colocar a esquerda, a Igreja Católica e a opinião pública contra os dominicanos. A teoria é a de que um agente da Central Intelligence Agency (CIA) estava infiltrado na ALN e forneceu as informações que levaram à morte de Marighella. Além disso, o guerrilheiro teria sido alvejado fora do carro em que estavam os dois dominicanos. Desta forma, eles não poderiam ser responsabilizados pela morte de Marighella. Já Gorender (1998, p. 197) não acreditava nessa versão: “[...] o meu silêncio de historiador significaria conivência com a versão divulgada por Frei Betto em curso no Brasil e no exterior. Silêncio inadmissível diante do compromisso que o historiador tem com a verdade". Para ele, Marighella foi executado dentro do carro onde estavam os dominicanos e o suposto envolvimento da CIA careceria de comprovação. Já Frei Betto, numa versão revisada de Batismo de sangue (2006), questionou o fato de que Gorender entrevistou vários guerrilheiros - como Paulo de Tarso Venceslau e Genésio Homem de Oliveira - para escrever Combate nas trevas e ignorou Yves Lesbaupin (ex-Frei Ivo).

\section{Ditadura Militar e Luta Armada sob a perspectiva de Daniel Aarão Reis}

Nascido no Rio de Janeiro em 26 de setembro de 1946, Daniel Aarão Reis ingressou na luta armada como membro da direção da Dissidência Comunista (futuro Movimento Revolucionário 8 de Outubro - MR-8) que, em ação com a ALN, capturou o embaixador dos Estados Unidos, Charles Burke Elbrick, em 1969. Assim como outros envolvidos no episódio, ele foi preso e torturado. Numa entrevista a cedida a Folha de S. Paulo, o historiador afirmou que "A tortura é um inferno. É feita para destruir você, e não só fisicamente. O objetivo é destruir a alma do prisioneiro. É uma vergonha que

\footnotetext{
5 Para Gaspari (2014, p. 67-69), Fleury [...] projetava a imagem de machão valente, quando na realidade sua fama derivava da bestialidade do meio que vivera e sua ascensão ao posto chefe dos janízaros da ditadura militar, do declínio dos padrões éticos dos comandantes militares da ocasião. Nunca na história brasileira um delinquente adquiriu sua proeminência. [...] Nos anos seguintes o delegado tornou-se um paradigma da eficácia da criminalidade na repressão política. Um raciocínio que começara com a ideia de que a tortura pode ser o melhor remédio para obter uma confissão transbordava para o reconhecimento de que um fora da lei pode ser o melhor agente para a defesa do Estado. Recompensando-o e protegendo-o, em 1971, por sugestão do CIE, o governo passou-lhe no pescoço a fita verde-amarela com a Medalha do Pacificador. Para maiores detalhes sobre a vida e a carreira profissional do delegado Fleury, ver o livro do jornalista Pervival de Souza, Autópsia do medo - vida e morte do delegado Sérgio Paranhos Fleury (2000).
} 
as Forças Armadas até hoje escondam esse episódio que mancha sua história (2014)”. Em junho de 1970, ele foi um dos presos políticos trocados pelo embaixador alemão Enrenfried Von Holleben.

Na década de 1970, Daniel Aarão Reis passou por vários países: Argélia, Chile, Cuba, França (onde cursou a faculdade de História) e Moçambique. Com a promulgação da Lei da Anistia, em 1979, retornou ao Brasil e se dedicou ao ofício de historiador e a carreira de professor universitário. Entre suas obras sobre a ditadura militar, destacam-se Imagens da revolução: documentos políticos das organizações clandestinas de esquerda dos anos 1961 a 1971 (1985), junto com Jair Ferreira de Sá, e A revolução faltou ao encontro: os comunistas no Brasil (1990). Outras obras de destaque são Luís Carlos Prestes: um revolucionário entre dois mundos (2014) e A revolução que mudou o mundo: Rússia, 1917 (2017). Na época do lançado do filme O que é isso, companheiro (1997), Aarão Reis foi um dos historiadores que contribuiu para o livro Versões e Ficções: o Sequestro da História (1997) e criticou a abordagem do diretor Bruno Barreto sobre a captura do embaixador dos Estados Unidos.

Inicialmente, abordaremos o tópico sobre a luta armada. Com relação ao livro A revolução faltou ao encontro: os comunistas no Brasil, Cardoso (2013, p. 9-10) afirma que Aarão Reis realizou

[...] uma avaliação das razões da derrota das organizações comunistas no contexto da ditadura militar, considerando que as nossas vanguardas experimentaram o mesmo processo de outras vanguardas mundiais, especialmente Argélia, Cuba e Moçambique. Mas, lamentavelmente, não alcançaram a vitória sustentada por aquelas. As motivações que levaram à derrota das esquerdas em 1964 constituem o objeto central da pesquisa, entrecortadas com recordações da luta armada e do tempo do exílio.

Conforme Aarão Reis (1990), um dos empecilhos para o êxito da luta armada foi o isolamento entre a sociedade e os guerrilheiros. Em outras palavras, as organizações clandestinas de esquerda adquiriram

[...] coesão interna em troca do afrouxamento dos laços com a sociedade. É a lógica dos estados-maiores revolucionários: viver a revolução como um processo iminente, à espreita da oportunidade favorável. De fato, de que valerá a intimidade com processos sociais não revolucionários? Senão para diminuir aspirações e corroer o ânimo revolucionário? (AARÃO REIS, 1990, p. 19)

O historiador salienta que os guerrilheiros realizavam tarefas internas (estudo teórico e debate político-teórico) e externas (o trabalho de massas, de agitação e propaganda). Também havia outras qualidades que as organizações político-militares exigiam de seus membros: “[...] sensibilidade política, capacidade teórica, alto nível ideológico, treinamento físico, preparação militar, confiança do povo e, sobretudo, 'compromisso com o seu destino'”. (AARÃO REIS, 1990, p. 123) Outro ponto abordado diz respeito à dívida que o militante possuía para com a organização que o acolheu. Isso porque a desistência poderia ser interpretada como um ato de traição. 
Já com relação à repressão, é afirmado que a luta armada foi derrotada através de diferentes expedientes, tais como o uso desmedido da violência e o controle dos meios de comunicação. Neste sentido, a "confissão" pública de guerrilheiros presos se tornou um exemplo da tentativa das autoridades de demonstrar que o comunismo era uma ameaça para a sociedade brasileira. Para se referir aos “arrependidos”, era utilizado o termo “desbundado”. Para Aarão Reis (apud Kushnir, p. 286-287),

[...] devemos ter, sempre, compaixão dos que não aguentaram os maus-tratos. Desbundado foi uma palavra inventada pelos caras 'duros' de vanguarda que, assim, se referiam desprezivelmente a todos que não viam com bons olhos a aventura das esquerdas armadas. Depois, passou a se referir especificamente às pessoas que cediam diante da tortura. Mais tarde, o termo tornou-se um genérico, designando, ambiguamente, seja os que eram contra a luta armada, desqualificando-os, seja os que cediam diante da tortura. Enfim, trata-se de um termo carregado de sentido pejorativo e deve ser usado com muito cuidado. Em tempo: os torturadores gostavam muito de utilizá-lo.

Outras contribuições de Daniel Aarão Reis para o debate historiográfico envolvem a discussão sobre a nomenclatura mais adequada para caracterizar o período ditatorial, o enfoque desmistificador das relações da sociedade civil/ditadura e, por último, a delimitação temporal que deslocaria o término da ditadura de 1985 para 1979. Com relação à questão da nomenclatura, Aarão Reis (2014) declarou numa entrevista à Folha de S. Paulo que

O termo ditadura militar era legítimo na luta política, mas é inócuo para compreender a história. Ele joga um manto sobre todos os civis que apoiaram a ditadura. Ao insistir que a ditadura era militar, põe na obscuridade as conexões civis que ela teve ao longo do tempo. A mídia jogou um papel importantíssimo. Os jornais quase unanimemente apoiaram o golpe. O que se quer, ao resgatar essas conexões civis, não é sair por aí fazendo caça às bruxas. É entender por que essa gente toda entrou na aventura da ditadura. Por muito tempo, falei isso quase sozinho. Na história, devemos nos afastar do militantismo.

Ao se referir ao termo ditadura civil-militar, Aarão Reis demonstra a importância de não minimizar a participação dos civis no golpe de 1964 e na manutenção das Forças armadas nas décadas seguintes. Podemos citar algumas entidades ${ }^{6}$ que apoiaram o golpe civil-militar: Conferência Nacional dos Bispos do Brasil (CNBB), Ordem dos Advogados do Brasil (OAB), o Instituto de Pesquisas e Estudos Sociais (IPES) e o Instituto Brasileiro de Ação Democrática (IBAD). Para Mattos e Júnior (2004), o IBAD era responsável pelo financiamento de políticos da oposição e atuava dentro do Congresso Nacional através da Ação Democrática Parlamentar (ADEP). De forma integrada, o IPES ficou responsável pela mobilização dos civis (por exemplo,

6 Uma exceção é a ABI (Associação Brasileira de Imprensa) que oficialmente nunca apoiou o golpe. Ao analisar as Atas das reuniões ordinárias e extraordinárias e do Boletim do Conselho Administrativo da ABI, entre 1964 e 1974, Rollemberg (2010, p.104) notou "[...] o tipo de luta encaminhado: eminentemente corporativa, de defesa dos jornalistas presos e da liberdade de imprensa". 
através dos meios de comunicação) contra o governo de João Goulart. Entretanto, é preciso assinalar que o apoio aos militares foi se diluindo no decorrer da década de 1970. No governo de João Figueiredo (1979-1985), a CNBB e OAB apoiaram o processo de redemocratização.

Ainda com relação ao apoio civil aos militares, destacamos a realização das Marchas da Família com Deus pela Liberdade, interpretadas como um de pedido por intervenção militar para afastar o "perigo comunista" que ameaçaria a família, Deus e a pátria. Após o golpe, tais passeatas legitimaram o golpe civil-militar, mesmo "[...] que em nenhum momento se reivindicou um regime de exceção prolongada durante a 'campanha anticomunista', e sim uma breve intervenção, que viesse 'arrumar a casa', moralizando as instituições” (PRESOT, 2010, p. 90). Já em 1968, Aarão Reis (1990, p. 64-65) percebeu a relação contraditória de uma parcela da sociedade brasileira com a ditadura militar:

A classe média oscilava: do apoio ao golpe à oposição. Mas os sinais começavam a inverter-se em 1968: parcelas ponderáveis preparavam-se para entrar alegremente no banquete do 'milagre econômico'. Simpatizavam com a luta pelas liberdades democráticas, mas havia limites que não tinham condições de transpor nem desejavam fazê-lo. 'Caminhavam' com Geraldo Vandré, mas também gostavam de passear de 'Calhambeque' com Roberto Carlos. Apreciavam o teatro e a poesia da pobreza e do engajamento, mas começavam a se embalar nas novelas da TV Globo. Revoltavam-se contra a repressão, mas eram atraídos pelas oportunidades do novo ciclo de prosperidade.

Neste sentido, a sociedade brasileira tem dificuldades em entender como participou de uma ditadura na qual o Estado perseguiu com extrema violência seus adversários políticos:

[...] de modo geral, a memória da sociedade tendeu a adquirir uma arquitetura simplificada: de um lado, a ditadura, um tempo de trevas, o predomínio da truculência, o reino da exceção, os chamados anos de chumbo. De outro, a nova república, livre, regida pela Lei, o reino da cidadania, a sociedade reencontrando-se com sua vocação democrática (AARÃO REIS 2005, p. 7-8).

Tal percepção incorreta da ditadura militar surgiu do processo político lento, gradual e controlado pelos detentores do poder que resultou na eleição indireta de Tancredo Neves para o cargo de presidente e, posteriormente, a posse do seu vice, José Sarney. No livro Ditadura e democracia no Brasil, Aarão Reis (2014) acredita que a polarização entre ditadura militar (sentido negativo) e democracia (sentido positivo) foi uma construção histórica que originou num verdadeiro pacto nacional, iniciado ainda no final da década de 1970, que objetivava acabar com a ditadura.

Partiu-se do princípio de que a "[...] a sociedade brasileira apenas suportara a ditadura, como alguém que tolera condições ruins que se tornaram de algum modo inevitáveis, mas que, cedo ou tarde, serão superadas, como estava, de fato, acontecendo". (AARÃO REIS, 2014, p. 8) Entende-se que se faz imprescindível não minimizar o fato de que uma parcela considerável da sociedade brasileira foi beneficiada naquele momento e que a apoiou por anos. Em vista disso, Aarão Reis 
(2014) declarou numa entrevista ao jornal Zero Hora que prefere utilizar “[...] somente o termo simples de 'ditadura'. Liderada por milicos, mas com ampla e decisiva participação civil”.

Com relação à delimitação temporal, percebemos que meios de comunicação e os livros didáticos difundiram a ideia de que ela acabou em 1985. Entretanto, Aarão Reis (2014) afirma que é possível “[...] falar no fim da ditadura a partir de 1979, quando é aprovada a Lei da Anistia e se revogam atos institucionais. Ditaduras, por definição, podem criar ou ignorar leis a seu bel-prazer. É o estado de exceção”. Entretanto, a vigência das leis criadas pela ditadura impossibilitava a democracia plena no Brasil. Desta forma, o autor percebe que a transição democrática começou em 1979 e terminou em 1988, com a promulgação da Nova Constituição que substituiu o que foi chamado na época de "entulho autoritário".

É interessante perceber que outra concepção sobre a delimitação temporal advém de um historiador com um posicionamento político diferente de Daniel Aarão Reis. Antônio Villa (2014), ligado ao Instituto Teotônio Villela, do PSDB, acredita que o Brasil não viveu uma ditadura entre 1964 e a promulgação do AI-5, em 1968, pois a efervescência cultural e política não seriam compatíveis com um regime autoritário. Ele também entende que o período entre 1979 e 1985 não pode ser enquadrado como ditadura em vista da promulgação da Lei da Anistia e as eleições diretas para governadores, em 1982. Desta forma, a ditadura no Brasil teria ocorrido somente entre 1968 (pós-AI-5) e 1979.

\section{Apontamentos Finais}

Procedimento de primeira ordem para os pesquisadores que se propõem a realizar trabalhos acadêmicos sobre a ditadura militar, a leitura da historiografia sobre o tema serve como introdução obrigatória para melhor compreender o período. Evento de grande impacto político e cujas influências ainda são sentidas na sociedade, a ditadura militar é um tema polêmico que suscita interesse do público (vide os numerosos livros publicados pelas grandes editoras) e gera debates acadêmicos. Desta forma, o presente artigo analisou alguns apontamentos da produção historiográfica de Jacob Gorender e Daniel Aarão Reis sobre a luta armada e a ditadura militar.

Com relação a Jacob Gorender, foram utilizadas entrevistas do historiador e uma de suas obras mais relevantes, Combate nas trevas. Um ponto essencial foi a sua percepção de que o momento propício para enfrentar a ditadura foi em 1964, uma vez que a conjuntura era favorável para a esquerda. Criticou-se, portanto, a postura do PCB na época - que também pode ser interpretada como uma autocrítica, pois Gorender foi dirigente do partido.

Outro tópico abordado foi a violência no período, seja praticada pela repressão (opressores) ou pelos oprimidos (guerrilheiros). No caso dos justiçamento, foram abordados os dois tipos: aquele praticado contra os inimigos da revolução (o empresário dinamarquês Henning Boilesen) ou companheiros sobre os quais havia suspeitas de traição (Márcio Leite de Toledo). Também foram salientadas as dificuldades dos guerrilheiros frente aos desafios cotidianos de fazer a revolução, além da polêmica envolvendo Jacob Gorender e Frei Betto sobre as circunstâncias da morte de Carlos Marighella. 
Já para analisar os elementos da obra historiográfica de Daniel Aarão Reis, foram utilizadas entrevistas e livros, principalmente A revolução faltou ao encontro: os comunistas no Brasil. Assim como Jacob Gorender, Aarão Reis abordou o funcionamento das organizações de esquerda e apontou as dificuldades no confronto com a repressão. Demonstramos que uma das táticas utilizadas pela ditadura militar foi permitir que os guerrilheiros presos fossem à televisão para expressar "arrependimento", o que originou o termo "desbundado".

É muito pertinente a visão crítica sobre a participação dos civis no golpe de 1964 e na manutenção da ditadura militar. Atualmente, a versão mais divulgada é a de que a sociedade resistiu aos abusos do governo militar e, desta forma, a democracia saiu vitoriosa. Aarão Reis denuncia tal deturpação de nossa história com vigor e argumentos convincentes. Neste sentido, também questiona a nomenclatura correta e a duração do período ditatorial.

Na condição de guerrilheiros, Jacob Gorender e Daniel Aarão Reis foram torturados pela repressão e sofreram as consequências da derrota da causa revolucionária: o primeiro permaneceu anos preso no Brasil e o segundo partiu para o exílio. Coincidentemente, empreenderam o caminho da pesquisa historiográfica para analisar de forma crítica o período ditatorial e os percalços da luta armada. Graças à valiosa contribuição deles, é possível compreender melhor o momento no Brasil.

\section{REFERÊNCIAS}

BETTO, Frei. Batismo de sangue: guerrilha e morte de Carlos Marighella. Civilização Brasileira: São Paulo, 1982.

BETTO, Frei. Batismo de sangue: guerrilha e morte de Carlos Marighella. 14. ed. rev. e ampliada. Rio de Janeiro: Rocco, 2006.

CARDOSO, Lucileide Costa. Memórias conflitantes e a produção de uma historiografia polemista sobre a atuação da esquerda armada no Brasil. 2013. Disponível em: http://www.snh2013. anpuh.org/resources/anais/27/1371311391_ARQUIVO_SNH-2013-TextocompletoLucileide. pdf. Acesso em: 12 dez. 2018.

GASPARI, Elio. A ditadura escancarada. 2. ed. Rio de Janeiro: Intrínseca, 2014. GORENDER, Jacob. Combate nas trevas. 5. ed. rev. ampl. São Paulo: Ática, 1998.

GORENDER, Jacob. Combate nas Trevas, de Jacob Gorender, há anos esgotado, é reeditado. São Paulo, 1987. Entrevista concedida para Renato Rocha Pitzer e Ricardo Figueiredo de Castro. Disponível em: http://www.correiocidadania.com.br/index.php?option=com content\&task=view\&id=9697\&Itemid=151. Acesso em: 12 dez. 2018.

GORENDER, Jacob. Entrevista a Jacob Gorender, quando do lançamento do livro Combate nas trevas. 1988. Disponível em: http://port.pravda.ru/cplp/brasil/17-06-2014/36913-jacob gorender-o/. Acesso em: 12 dez. 2016. Entrevista concedida para Mario Maestri.

GORENDER, Jacob. Entrevista à Teoria e Debate. Disponível em: https://www.marxists.org/ portugues/gorender/1990/07/entrevista.htm Acesso em: 12 dez. 2018.

JOSÉ, Emiliano. A Revolução de Jacob Gorender. Carta Capital, 2013. Disponível em: http://www. cartacapital.com.br/cultura/a-revolucao-de-jacob-gorender-6327.html. Acesso em: 7 dez. 2018. 
KUSHNIR, Beatriz. Desbundar na TV: militantes da VPR e seus arrependimentos. In: QUADRAT, Samantha; ROLLEMBERG, Denise (org.). A construção social dos regimes autoritários: Brasil e América Latina. Rio de Janeiro: Civilização Brasileira, 2010. v. 3, p. 279-304.

MATTOS, Marco Aurélio Vannucchi L. de; JÚNIOR, Walter Cruz Swensson. Contra Inimigos da Ordem. A repressão política do regime militar brasileiro (1964-1985). Rio de Janeiro: DP e A, 2004.

Militar, sim. Mas nem tanto. Revista de História da Biblioteca Nacional. 2012. Disponível em: http://www.revistadehistoria.com.br/secao/reportagem/militar-sim-mas-nem-tanto. Acesso em: 10 fev. 2017. https://doi.org/10.15448/1980-3729.2011.2.9472

PRESIDÊNCIA DA REPÚBLICA. Nota de pesar da presidenta Dilma Rousseff pelo falecimento de Jacob Gorender. Disponível em: http://www.biblioteca.presidencia.gov.br/presidencia/ ex-presidentes/dilma-rousseff/notas-oficiais/notas-oficiais/nota-de-pesar-da-presidenta-dilma-rousseff-pelo-falecimento-de-jacob-gorender. Acesso em: 23 fev. 2019. https://doi. org/10.18617/liinc.v15i1.4571

PRESOT, Aline. Celebrando a "Revolução": as marchas da família com Deus pela liberdade e o golpe de 1964. In: QUADRAT, Samantha; ROLLEMBERG, Denise (org.). A construção social dos regimes autoritários: Brasil e América Latina. Rio de Janeiro: Civilização Brasileira, 2010. p. 71-96. v. 3. https://doi.org/10.4025/6cih.pphuem.166

REIS, Daniel Aarão. A revolução faltou ao encontro. Comunistas no Brasil. São Paulo: Brasiliense, 1990.

REIS, Daniel Aarão. 'A luta armada se esqueceu de fazer consulta ao povo', afirma historiador. Folha de S. Paulo, 2014. Entrevista concedida para Bernardo Mello Franco. Disponível em: http://www1.folha.uol.com.br/poder/2014/03/1432835-a-luta-armada-se-esqueceu-de-fazer-consulta-ao-povo-afirma-historiador.shtml. Acesso em: 12 jan. 2019. https://doi. org/10.26512/2016.02.t.20512

REIS, Daniel Aarão. Entrevista com o historiador Daniel Aarão Reis sobre a ditadura: "Liderada por milicos, com participação civil”. Zero Hora, Porto Alegre, 2014. Entrevista concedida para Juliana Bublitz. Disponível em: http:/zh.clicrbs.com.br/rs/entretenimento/noticia/2014/03/ entrevista-com-o-historiador-daniel-aarao-reis-sobre-a-ditadura-liderada-por-milicos-com-participacao-civil-4460416.html. Acesso em: 04 dez. 2018. https://doi.org/10.4025/dialogos. $\underline{\mathrm{V} 19 \mathrm{i} 2.1146}$

REIS, Daniel Aarão. Ditadura e democracia no Brasil: do golpe de 1964 à Constituição de 1964. Rio de Janeiro: Zahar, 2014. https://doi.org/10.22228/rt-f.v8i2.442

REIS, Daniel Aarão. Ditadura militar, esquerdas e sociedade. 3. ed. Rio de Janeiro: Jorge Zahar Ed., 2005.

ROLLEMBERG, Denise. As trincheiras da memória. A associação Brasileira de Imprensa e a ditadura (1964-1974). In: QUADRAT, Samantha; ROLLEMBERG, Denise (org.). A construção social dos regimes autoritários: Brasil e América Latina. Rio de Janeiro: Civilização Brasileira, 2010. p. 97-144. v. 3.

ROLLEMBERG, Denise. Esquerdas revolucionárias e luta armada. In: FERREIRA, Jorge; NEVES, Lucilia de Almeida. O tempo da ditadura: regime militar e movimentos sociais em fins do século XX. 3. ed. Rio de Janeiro: Civilização Brasileira, 2009. p. 43-91.

VILLA, Marco Antonio. Ditadura à brasileira: a democracia golpeada à esquerda e à direita. São Paulo: Leya, 2014 . 
Recebido em: 26/03/2019

Aprovado em: 24/10/2019

\section{Vinícius Viana Juchem}

Endereço para correspondência:

Universidade do Vale do Rio dos Sinos - Unisinos

Av. Unisinos, 950 - Cristo Rei

São Leopoldo / RS, Brasil.

CEP: $93022-750$ 